\title{
UJI EFEK ANALGESIK EKSTRAK ETANOL DAUN KELOR (Moringa oleifera Lam.) PADA TIKUS PUTIH JANTAN GALUR WISTAR (Rattus norvegicus)
}

\section{ANALGESIC EFFECT TEST OF Moringa oleifera Lam. LEAF ETHANOL EXTRACT IN MALE WHITE RATS WISTAR STRAIN (Rattus norvegicus)}

\author{
Alyah Ananta Pratiwi Tamimi ${ }^{1 \text { ** }}$, Edwin de Queljoe ${ }^{1)}$, Jainer Pasca Siampa ${ }^{1)}$ \\ 1) Program Studi Farmasi FMIPA UNSRAT Manado, 95115 \\ *e-mail : aptalyah@gmail.com
}

\begin{abstract}
Analgesic medicinals are medicinals that can inhibit pain. Moringa leaves (Moringa oleifera Lam.) are known to contains alkaloid and flavonoid which have analgesic effects. The purpose of this study was to determine the analgesic effects of the ethanol extract of Moringa leaves on male white rats wistar strain (Rattus norvegicus). A total of 15 rats were divided into 5 treatment groups, namely the negative control group (CMC), positive control group (paracetamol), and the group of ethanol extract of Moringa leaves with different doses of $0.1 \mathrm{~g}, 0.2 \mathrm{~g}$, and $0.4 \mathrm{~g}$. Rat response was observed before giving test material and after giving test material from the $30^{\text {th }}, 60^{\text {th }}, 90^{\text {th }}$, and $120^{\text {th }}$ minutes. Data were analyzed using ANOVA then continued with LSD test. The results showed that the ethanol extract of Moringa leaves with dosages of $0.1 \mathrm{~g}, 0.2 \mathrm{~g}$, and $0.4 \mathrm{~g}$ had an analgesic effect on male white rats wistar strain. And among these three doses the best in providing analgesic effect is a dose of $0.4 \mathrm{~g}$.
\end{abstract}

Keywords: Analgesic, Moringa leaf (Moringa oleifera Lam.), Rattus norvegicus.

\begin{abstract}
ABSTRAK
Obat analgesik merupakan obat yang dapat menghambat rasa nyeri. Daun kelor (Moringa oleifera Lam.) diketahui mengandung alkaloid dan flavonoid yang memiliki efek analgesik. Tujuan penelitian ini untuk mengetahui adanya efek analgesik dari ekstrak etanol daun kelor (Moringa oleifera Lam.) pada tikus putih jantan galur wistar (Rattus norvegicus). Sebanyak 15 ekor tikus dibagi 5 kelompok perlakuan, yaitu kelompok kontrol negatif, kelompok kontrol positif, dan kelompok ekstrak etanol daun kelor dengan dosis berbeda $0,1 \mathrm{~g}, 0,2 \mathrm{~g}$, dan 0,4 g. Respon tikus diamati sebelum pemberian bahan uji dan setelah pemberian bahan uji dari menit ke 30,60, 90, dan 120. Data dianalisis menggunakan ANOVA kemudian dilanjutkan uji LSD. Hasil penelitian menunjukkan bahwa ekstrak etanol daun kelor dengan dosis $0,1 \mathrm{~g}$ $0,2 \mathrm{~g}$, dan 0,4 g memiliki efek analgesik terhadap tikus putih jantan galur wistar. Dan diantara ketiga pemberian dosis tersebut yang paling baik dalam memberikan efek analgesik yaitu dosis $0,4 \mathrm{~g}$.
\end{abstract}

Kata kunci: Analgesik, Daun Kelor (Moringa oleifera Lam.), Rattus norvegicus. 


\section{PENDAHULUAN}

Rasa nyeri adalah salah satu masalah yang umumnya terjadi pada masyarakat dan juga salah satu penyebab paling sering pasien akan datang ke dokter, karena rasa nyeri mengganggu fungsi sosial dan kualitas hidup penderitanya. Rasa nyeri akan disertai dengan respon stres, berupa meningkatnya rasa cemas, denyut jantung, tekanan darah, dan frekuensi napas. Nyeri yang berlanjut atau tidak ditangani secara kuat, memicu respon stres yang berkepanjangan, yang akan menurunkan daya tahan tubuh dengan menurunkan fungsi imun, mempercepat kerusakan jaringan, laju metabolisme, pembekuan darah dan retensi cairan, sehingga akhirnya akan memperburuk kualitas kesehatan (Hartwig dan Wilson, 2006).

Nyeri bisa diatasi dengan menggunakan obat analgesik. Analgesik adalah zat-zat yang mengurangi atau menghalau rasa nyeri tanpa menghilangkan kesadaran. Analgesik dibagi menjadi dua kelompok yaitu analgesik opioid dan analgesik non-opioid (Tjay dan Rahardja, 2007). Analgesik opioid merupakan kelompok obat yang selain memiliki efek analgesik, juga memiliki efek seperti opium (Gunawan et al., 2008). Analgesik nonopioid merupakan analgesik pilihan pertama yang diberikan untuk penatalaksanaan nyeri ringan sampai sedang. Contoh obat analgesik non-opioid yaitu parasetamol, aspirin, ibuprofen, dan lain-lain (Ikawati, 2011). Parasetamol merupakan pilihan pertama bagi penanganan demam dan nyeri sebagai antipiretik dan analgesik.
Parasetamol berguna untuk mengatasi nyeri ringan sampai sedang, seperti nyeri kepala. Parasetamol sendiri mempunyai efek hepatotoksik (Al-Muqsith, 2015). Analgesik yang berasal dari herbal cenderung tidak menimbulkan efek samping, salah satu tanaman yang dapat digunakan sebagai analgesik adalah daun kelor (Moringa oleifera Lam.). Tanaman kelor sangat banyak dijumpai di tengah-tengah masyarakat, di samping itu pembudidayaannya pun sangat mudah. Daun kelor mengandung alkaloid dan flavonoid yang bersifat analgesik. Kandungan alkaloid daun kelor terdiri dari alkaloid moringin, moringinin, dan pterigosperinin. Zat-zat inilah yang berkhasiat mengurangi rasa nyeri. Flavonoid juga dapat mengurangi rasa nyeri terutama pada nyeri persendian akibat reumatik (Al-Muqsith, 2015).

\section{METODOLOGI PENELITIAN}

\section{Waktu dan Tempat Penelitian}

Penelitian dilakukan pada bulan November 2019 sampai Januari 2020 di Laboratorium Lanjutan Farmasi Program Studi Farmasi Fakultas Matematika dan Ilmu Pengetahuan Alam Universitas Sam Ratulangi, Manado.

\section{Alat dan Bahan}

Alat

Alat-alat yang akan digunakan pada penelitian ini antara lain alat-alat gelas (Pyrex), oven, blender (Philips $\left.{ }^{\circledR}\right)$, pengayak, wadah, pisau, batang pengaduk, sudip, timbangan analitik (ADAM,KERN), timbangan tepung, sarung tangan, kertas 
saring, pipet ukur, lumpang dan alu, termometer, hot plate (IKA), stopwatch, disposable syringe $1 \mathrm{ml}$, aluminium foil, toples, dan sonde oral.

\section{Bahan}

Dalam penelitian ini bahan yang digunakan yaitu daun kelor (Moringa oleifera Lam.), etanol 96\%, aquadest, CMC, tablet parasetamol $500 \mathrm{mg}$, dan makanan hewan uji.

\section{Hewan Uji}

Objek yang digunakan dalam penelitian ini merupakan tikus putih jantan galur wistar (Rattus novergicus) yang berumur 2-3 bulan dan berat badan 150-200 g dengan jumlah 15 ekor.

\section{Rancangan Penelitian}

Penelitian ini menggunakan rancangan penelitian eksperimental laboratorium dengan menggunakan tikus putih jantan galur wistar (Rattus novergicus) sebagai hewan percobaan. Perlakuan dibagi dalam 5 kelompok, dalam kelompok masing-masing terdiri dari 3 ekor tikus yang sudah diadaptasikan terlebih dahulu terhadap lingkungan kurang lebih 10 hari. Pembagian kelompok perlakuan sebagai berikut :

$\mathrm{K}(-)$ : diberikan CMC sebanyak $1 \mathrm{ml}$, $\mathrm{K}(+)$ : diberikan parasetamol dosis $9 \mathrm{mg}$, KP 1: diberikan ekstrak etanol daun kelor 0,1 g, KP 2: diberikan ekstrak etanol daun kelor 0,2 g, KP 3: diberikan ekstrak etanol daun kelor $0,4 \mathrm{~g}$.

\section{Pembuatan Simplisia dan Proses Ekstraksi}

Daun kelor (Moringa oleifera Lam.) yang diambil dicuci bersih sebanyak 4,4 kg sampel daun kelor. Kemudian daun kelor dikeringkan dengan cara di angin-anginkan hingga daunnya mengering. Sampel yang sudah kering di blender lalu diayak dengan pengayak. Daun kelor ditimbang sebanyak $400 \mathrm{~g}$ dimasukkan kedalam wadah, kemudian ditambahkan pelarut etanol $96 \%$ sebanyak $2000 \mathrm{ml}$ dengan perbandingan 1:5 sampai sampel terendam secara keseluruhan kemudian sampel ditutup, perendaman dilakukan selama 5 hari dan terlindung dari cahaya. Selama perendaman dilakukan pengadukan setiap hari. Setelah 5 hari, dilakukan penyaringan menggunakan kertas saring menghasilkan filtrat dan debris. Selanjutnya dilakukan proses remaserasi ekstrak dengan etanol 96\% sebanyak 1200 ml dengan perbandingan 1:3 selama 2 hari. Filtrat hasil dari maserasi dan remaserasi digabungkan dan dipekatkan menggunakan oven pada suhu $40^{\circ} \mathrm{C}$ sampai diperoleh ekstrak kental.

\section{Pembuatan Larutan CMC}

Sebanyak 1 g CMC ditaburkan dalam beaker glass dan dimasukkan aquadest sebanyak $100 \mathrm{ml}$ kemudian dipanaskan menggunakan hot plate, diaduk sampai mengembang dan homogen. Suspensi CMC juga digunakan sebagai larutan stock dan diambil $10 \mathrm{ml}$ untuk setiap kelompok perlakuan. 


\section{Penyiapan Hewan Uji}

Hewan uji yang digunakan dalam penelitian ini adalah tikus putih jantan galur wistar (Rattus novergicus) sebanyak 15 ekor dan dibagi dalam 5 kelompok perlakuan dimana setiap kelompok terdiri dari 3 ekor tikus dengan berat 150-200 g. Sebelum dilakukan pengujian, hewan uji dipuasakan selama 8 jam namun tetap diberi minum.

\section{Pemberian Ekstrak dan Larutan Pembanding}

1) Ekstrak etanol daun kelor

Takaran konversi dosis untuk manusia dengan berat badan $70 \mathrm{~kg}$ terhadap tikus dengan berat badan $200 \mathrm{~g}$ adalah 0,018. Pada penelitian yang menggunakan subjek manusia, daun kelor diberikan dalam bentuk simplisia dengan dengan dosis 10 g/hari (Stohs dan Hartman, 2015).

Maka untuk dosis tikus:

$$
\begin{aligned}
& =10 \times 0,018 \\
& =0,18 \mathrm{~g}
\end{aligned}
$$

Dalam percobaan digunakan dosis bertingkat ekstrak daun kelor yang terbagi:

Kelompok perlakuan $1=0,1 \mathrm{~g}$

Kelompok perlakuan $2=0,2 \mathrm{~g}$

Kelompok perlakuan $3=0,4 \mathrm{~g}$

2) Kontrol Positif

Tiap tablet parasetamol mengandung $500 \mathrm{mg}$. Takaran konversi dosis parasetamol pada manusia dengan berat badan $70 \mathrm{~kg}$ dan pada tikus dengan berat badan $200 \mathrm{~g}$ adalah 0,018 .

Maka dosis untuk tikus adalah :

$=500 \mathrm{mg} \times 0,018$

$=9 \mathrm{mg}$
3) Kontrol Negatif

Kontrol negatif diberikan CMC diambil sebanyak $1 \mathrm{ml}$ dan diberikan pada tiap hewan uji kontrol negatif.

\section{Metode Stimulasi Panas}

Uji efek analgesik menggunakan metode stimulasi panas diberikan secara konduksi dikenal dengan metode Hot Plate oleh Wolf dan Mc Donald yaitu dengan cara memasukkan tikus ke dalam beaker glass yang telah dipanaskan diatas hot plate pada suhu $52^{\circ} \mathrm{C}$ sebagai stimulus nyeri dan tikus akan memberikan respon dalam bentuk menjilat kaki dan atau melompat (Domer, 1971).

\section{Pengujian Efektivitas Analgesik}

Langkah-langkah pengujian efek analgesik pada hewan uji adalah sebagai berikut :

a. Beaker glass diletakkan diatas hot plate yang dipanaskan hingga $52^{\circ} \mathrm{C}$. Setelah suhu mencapai $52^{\circ} \mathrm{C}$ tikus dimasukkan kedalam beaker glass tersebut.

b. Setelah tikus ada di dalam beaker glass maka responnya diamati, yaitu berupa gerakan menjilat kaki dan atau melompat, pengamatan dilakukan selama 1 menit.

c. Kelompok kontrol negatif diberikan CMC, kelompok kontrol positif diberikan parasetamol dan kelompok perlakuan diberikan ekstrak etanol daun kelor. Tikus lalu diistirahatkan untuk diamati kembali pada menit ke30 
d. Pengamatan dilakukan hingga menit ke-120, dengan interval waktu 30 menit untuk setiap pengamatan.

e. Pengamatan dilakukan sebanyak 5 kali yaitu :

1. Sebelum pemberian bahan uji

2. Menit ke-30

3. Menit ke-60

4. Menit ke-90

5. Menit ke-120

\section{Analisis Data}

Data hasil pengamatan dikumpulkan dan disajikan dalam bentuk tabel, grafik dan menggunakan uji statistik parametik One Way ANOVA (Analysis Of Variance). Bila hasil uji One Way ANOVA menunjukan perbedaan yang signifikan dari pengujian ekstrak etanol daun kelor (Moringa oleifera Lam.) terhadap tikus putih jantan galur wistar (Rattus noervegicus) maka dilanjutkan dengan uji LSD (Least Significant Difference) untuk mengetahui signifikan dari perbedaan rata-rata kelompok perlakuan.

\section{HASIL DAN PEMBAHASAN}

Hasil penelitian berikut ini merupakan data yang diperoleh dari 5 kelompok perlakuan dengan masing-masing kelompok terdiri dari 3 ekor hewan uji. Rata-rata penurunan respon tikus (jilatan dan lompatan) terhadap kontrol negatif, kontrol positif, dan ekstrak etanol daun kelor dapat dilihat sebagai berikut :

Tabel 1. Hasil Rata-rata Penurunan Respon Tikus Sebelum dan Sesudah Pemberian Bahan Uji

\begin{tabular}{cccccc}
\hline $\begin{array}{c}\text { Kelompok } \\
\text { Perlakuan }\end{array}$ & $\begin{array}{c}\text { Sebelum } \\
\text { Pemberian } \\
\text { Bahan Uji }\end{array}$ & Menit ke-30 & Menit ke-60 & Menit ke-90 & Menit ke-120 \\
\hline Kontrol Negatif & 19,7 & 18 & 19,3 & 19 & 20,3 \\
Kontrol Positif & 20 & 12,7 & 6 & 1 & 0 \\
KP 1 & 18,7 & 13 & 6,67 & 1,33 & 0,33 \\
KP 2 & 20 & 7 & 4,67 & 0,67 & 0 \\
KP 3 & 19,7 & 4 & 2,33 & 0 & 0 \\
\hline
\end{tabular}

Keterangan: K(-) : Kelompok kontrol negatif (CMC), K(+) : Kelompok kontrol positif dosis 9mg, KP 1 : Kelompok perlakuan ekstrak daun kelor dosis 0,1 g, KP 2 : Kelompok perlakuan ekstrak daun kelor dosis 0,2 g, KP 3 : Kelompok perlakuan ekstrak daun kelor dosis 0,4 g

Berdasarkan grafik, terlihat dengan jelas bahwa pada pemberian bahan uji yaitu kontrol positif dan ekstrak etanol daun kelor respon nyeri yang ditunjukkan oleh hewan uji mulai menurun dari menit ke-30 hingga menit ke-120, sedangkan pada pemberian bahan uji kontrol negatif respon nyeri yang ditunjukkan oleh hewan uji disetiap menit pengujian semakin meningkat. 


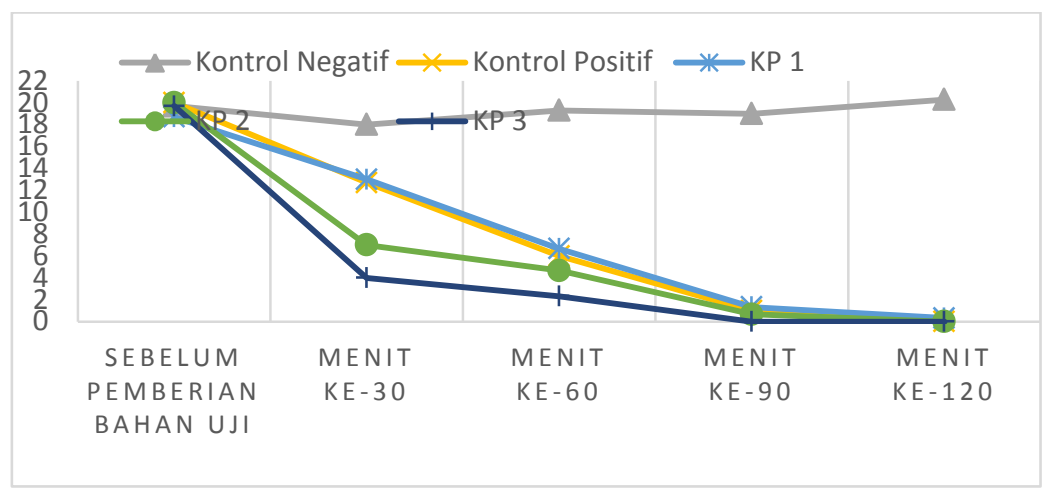

Gambar 1. Grafik Penurunan Rata-rata Respon Tikus

Tanaman kelor (Moringa oleifera Lam.) khususnya yang dipakai dalam penelitian ini yaitu bagian daunnya telah digunakan secara luas untuk mengobati berbagai penyakit. Penelitian ini dilakukan untuk mengetahui ada tidaknya efek analgesik dari ekstrak etanol daun kelor terhadap hewan uji yang menggunakan metode stimulasi panas untuk merangsang rasa nyeri.

Rasa nyeri merupakan sensasi yang perlu diatasi dan adanya aktivitas menekan rasa nyeri yang ditimbulkan oleh ekstrak daun kelor disebabkan karena adanya senyawa aktif yang terkandung dalam daun kelor. Hal ini didukung oleh penelitian sebelumnya yang dilakukan oleh Patel et al (2014), bahwa hasil uji fitokimia daun kelor menunjukan adanya kandungan flavonoid, alkaloid, steroid, tanin, saponin, dan terpenoid. Flavonoid berkhasiat sebagai analgesik yang mekanisme kerjanya menghambat kerja enzim siklooksigenase. Dari penghambatan enzim siklooksigenase tersebut yang akan mengurangi produksi prostaglandin sehingga dapat mengurangi rasa nyeri. Alkaloid memiliki fungsi sebagai penghambat fase penting dalam biosintesis prostaglandin, yaitu pada lintasan siklooksigenase dalam jalur metabolisme asam arakidonat, sedangkan saponin digolongkan ke dalam triterpenoid dan steroid saponin yang bersifat sebagai anti inflamasi, analgesik, dan sitotoksik (Wemay et al., 2013). Berdasarkan dari uraian diatas ekstrak etanol daun kelor berpotensi sebagai analgesik terhadap tikus putih.

Hewan uji yang digunakan yaitu tikus putih jantan karena kondisi biologisnya lebih stabil dibandingkan dengan tikus betina. Rasa nyeri disebabkan oleh rangsangan mekanik atau kimiawi, panas atau listrik yang dapat menimbulkan kerusakan jaringan dan melepaskan zat yang disebut mediator nyeri (Tjay dan Rahardja, 2007). Rangsangan nyeri yang diberikan pada penelitian ini adalah metode stimulasi panas, dengan cara memasukkan tikus ke dalam beaker glass yang sudah diletakkan di atas hot plate pada suhu $52^{\circ} \mathrm{C}$ sebagai stimulus nyeri. Keuntungan dari metode stimulasi panas adalah rangsangannya alami, mudah dikontrol, tidak menyebabkan kerusakan jaringan walaupun rangsangan untuk menimbulkan rasa sakit dilakukan berkali-kali, dan dapat digunakan pada subjek yang bergerak ataupun tidak bergerak (Domer, 1971). Respon yang terlihat seperti 
menjilat kaki atau melompat digunakan sebagai indikator respon hewan uji terhadap stimulus nyeri yang dikonduksi oleh panas. Waktu disetiap tikus sedang menjilat kakinya atau mecoba melompat keluar dari wadah digunakan sebagai data waktu respon rasa nyeri (Lanhers et al., 1992). Stimulasi panas dalam penelitian ini mengunakan suhu $52^{\circ} \mathrm{C}$ karena suhu kritis rata-rata nyeri sebesar $45^{\circ} \mathrm{C}$ saat seseorang mulai merasakan sakit dan reseptor panas mempunyai respon terhadap suhu $30-45^{\circ} \mathrm{C}$. Kemudian suhu diatas $45^{\circ} \mathrm{C}$ dimana mulai terjadi kerusakan jaringan akibat panas dan sensasinya berubah menjadi nyeri. Nyeri ini disebabkan oleh stimulus panas yang merangsang reseptor nyeri yang sensitif terhadap suhu panas atau dingin (Guyton, 1994). Efek analgesik dapat ditunjukkan dengan berkurangnya jumlah respon tikus dalam bentuk menjilat kaki dan melompat. Selang waktu antara pemberian stimulus nyeri dan terjadinya respon disebut waktu reaksi. Waktu reaksi ini dapat diperpanjang oleh obat-obat analgesik. Perpanjangan waktu reaksi ini dapat dijadikan sebagai ukuran mengevaluasi aktivitas analgesik (Turner, 1965).

Hasil perhitungan rata-rata respon tikus sebelum dan setelah perlakuan dengan selang waktu 30 menit ini menjelaskan bahwa penurunan respon tikus paling kecil yaitu terlihat pada kelompok perlakuan kontrol negatif, sedangkan kelompok perlakuan kontrol positif parasetamol dan ekstrak etanol daun kelor dengan dosis 0,1 $\mathrm{g}, 0,2 \mathrm{~g}$, dan 0,4 g respon tikus hampir sama. Hal ini menunjukan bahwa suspensi parasetamol dan ekstrak etanol daun kelor mampu menurunkan respon tikus pada efek analgesik.

Pada kelompok kontrol negatif yang diberikan suspensi CMC, sebelum dan setelah pemberian bahan uji hingga menit ke-120 respon tikus tidak mengalami penurunan, dari menit ke-30 hingga menit ke-120 respon tikus justru semakin tinggi. Hal ini menunjukan bahwa kontrol negatif yang digunakan tidak mengandung zat aktif yang dapat mengurangi rasa nyeri. Pada kelompok positif yang diberikan dengan suspensi parasetamol, sebelum dan setelah pemberian bahan uji dari menit ke-30 hingga menit ke-120 menunjukan terjadinya penurunan respon rata-rata hewan uji terhadap rangsangan nyeri. Efek analgesik dari kontrol positif tetap terlihat sampai akhir pengujian dan mencapai puncaknya pada menit ke-120. Hal ini disebabkan karena parasetamol ini sudah terbukti memiliki efek analgesik yang secara luas telah digunakan oleh masyarakat. Parasetamol memang sudah terbukti secara teoritis dapat menghambat sintesis prostaglandin.

Hasil pengujian pada kelompok perlakuan yang diberikan dosis berbeda, menunjukan adanya efek analgesik ekstrak daun kelor pada hewan uji. Hal ini dapat dilihat penurunan rata-rata respon nyeri pada hewan uji dari sebelum pemberian dan setelah pemberian bahan uji. Pada kelompok perlakuan satu diberi ekstrak daun kelor dengan dosis $0,1 \mathrm{~g}$ dan hasil menunjukan adanya penurunan respon tikus pada menit ke-30 dan terus mengalami penurunan hingga menit ke-120. Ekstrak daun kelor dengan dosis kecil 0,1 g yang diberikan dan kelompok kontrol positif memiliki 
kemampuan menghambat nyeri yang hampir sama, namun pada pemberian ekstrak kelompok perlakuan satu ini tidak sebaik dengan efek analgesik yang ditunjukkan oleh pemberian kontrol positif. Kelompok perlakuan dua diberi ekstrak daun kelor 0,2 $\mathrm{g}$ dan hasil menunjukan adanya penurunan respon tikus dari menit ke-30 dan terus mengalami penurunan hingga menit ke-90, kemudian pada menit ke-120 respon nyeri pada hewan uji mulai hilang. Hal ini menunjukan bahwa ekstrak daun kelor dengan dosis 0,2 $\mathrm{g}$ memiliki efek analgesik. Kelompok perlakuan tiga diberi ekstrak daun kelor dengan dosis 0,4 g dan hasil menunjukan adanya penurunan respon nyeri terhadap hewan uji dari menit ke-30 dan terus mengalami penurunan hingga menit ke-60, kemudian pada menit ke-90 hingga menit ke-120 respon nyeri pada hewan uji mulai hilang.

Data penelitian yang telah didapatkan dilakukan uji statistik menggunakan aplikasi SPSS versi 25 untuk memperoleh data yang lebih spesifik pada efek analgesik ekstrak etanol daun kelor dari penelitian yang dilakukan dengan menggunakan metode One Way ANOVA, kemudian dilanjutkan dengan uji LSD (Least Significant Difference). Dari uji One Way ANOVA diperoleh nilai signifikan = 0,044 (sig<0,05) yang berarti ada perbedaan yang bermakna antara kelima kelompok perlakuan. Dilihat dari data tersebut bahwa ekstrak etanol daun kelor memiliki efek analgesik yang mampu mengurangi respon nyeri pada hewan uji. Uji One Way ANOVA yang telah diketahui hasilnya, maka dilakukan Test of homogenity of variance yang bertujuan untuk mengetahui apakah dari beberapa kelompok perlakuan berasal dari populasi dan varian yang sama atau tidak, yang artinya data terdistribusi homogen. Data yang diperoleh terdapat nilai signifikan $=0,137($ sig $>0,05)$ yang berarti tidak ada perbedaan yang bermakna antara kelima kelompok tersebut atau dengan kata lain data terdistribusi homogen.

Dilanjutkan dengan uji LSD (Least Significant Difference) untuk melihat adanya perbedaan nilai rata-rata penurunan respon hewan uji dari sebelum perlakuan dan sesudah perlakuan pada menit ke-30, 60, 90, 120, antara kelima kelompok perlakuan yang berbeda-beda yaitu kontrol negatif CMC, kontrol positif parasetamol dosis 9 mg dan kelompok perlakuan ekstrak dengan dosis 0,1 g, 0,2 g dan 0, $4 \mathrm{~g}$. Dimana hasil pengujian LSD menunjukkan bahwa pada kontrol negatif terdapat perbedaan dengan kontrol positif dan kelompok perlakuan ekstrak. Sedangkan kelompok perlakuan ekstrak etanol daun kelor tidak mengalami perbedaan dengan kontrol positif. Ini menunjukkan bahwa pemberian ekstrak etanol daun kelor memiliki efek analgesik untuk mengurangi respon hewan uji.

Dari data-data yang telah diperoleh dinyatakan bahwa kandungan daun kelor menunjukkan aktivitas sebagai analgesik karena mengandung flavonoid dan alkaloid sehingga mampu menghambat enzim siklooksigenase yang berperan dalam biosintesis prostaglandin sebagai mediator pembentuk radang yang disertai rasa nyeri.

\section{KESIMPULAN}

Hasil penelitian menunjukkan bahwa pemberian ekstrak etanol daun kelor (Moringa oleifera Lam.) dengan dosis 
berbeda yaitu $0,1 \mathrm{~g}, 0,2 \mathrm{~g}$ dan $0,4 \mathrm{~g}$ yang diberikan pada tikus putih jantan galur wistar (Rattus norvegicus) memiliki efek analgesik ditinjau dari penurunan respon nyeri yang ditunjukkan oleh hewan uji. Dan diantara ketiga pemberian dosis berbeda tersebut yang paling baik dalam memberikan efek analgesik adalah pemberian ekstrak etanol daun kelor dengan dosis besar $0,4 \mathrm{~g}$.

\section{SARAN}

Perlu dilakukan penelitian uji efek analgesik dengan menggunakan variasi dosis agar diperoleh dosis minimum, maksimum, dan dosis toksik sehingga dapat diperoleh dosis yang optimal untuk menunjang tingkat keamanan penggunaan daun kelor sebagai sediaan herbal. Serta dilakukan lanjutan pengujian uji toksisitas kronik dan subkronik.

\section{DAFTAR PUSTAKA}

Al-Muqsith. 2015. Uji Daya Analgetik Infusa Daun Kelor (Moringa oleifera, L) Pada Mencit (Mus musculus) Betina. Lentera. 15(14): 59-63.

Domer, F.R. 1971. Animal Experimental in Pharmacological Analysis. Charles Thomas Publisher, USA.

Gunawan, S.G., R. Setiabudy., Nafrialdy., dan Elysabeth. 2008. Farmakologi dan Terapi. Edisi ke-5. Departemen Farmakologi dan Terapeutik Fakultas Kedokteran Universitas Indonesia, Jakarta.

Guyton, A.C. 1994. Fisiologi Kedokteran Edisi ke-7. Terjemahan Ken Ariata Tengadi. EGC, Jakarta.
Hartwig., dan Wilson. 2006. Patofisiologi: Konsep Klinis Proses-Proses Penyakit. EGC, Jakarta.

Ikawati, Z. 2011. Farmakoterapi Penyakit Sistem Saraf Pusat. Bursa Ilmu, Yogyakarta

Lanhers, M.C., J. Fleurentin., F. Mortier., A. Vinche., and C. Younos. 1992. AntiInflamamatory and Analgesic Effects of an Aqueous Extract of Harpagophytum procumbens. Planta Medica. 5(1): 117-123.

Patel, P., Nivedita., Dhara., S. Desai., and D. Meshram. 2014. Phytochemical Analysis and Antifungal Activity of Moringa oleifera. International Journal of Pharmaceutical Sciences. 6(5): 144-147.

Stohs, S.J., and M.J. Hartman. 2015. Review of The Safety and Efficacy of Moringa oleifera. Phytotherapy Research. 29(6): 796-804.

Tjay, T., dan K. Rahardja. 2007. Obat-obat Penting, Khasiat, Penggunaan dan Efek Sampingnya. Edisi ke-6. PT Elex Media Komputindo Kelompok Gramedia, Jakarta.

Turner, R.A. 1965. Screening Methods In Pharmacology. Academia Press, New York.

Wemay, M.A., Fatimawali., dan F. Whantouw. 2013. Uji Fitokimia dan Aktivitas Analgesik Ekstrak Etanol Tanaman Kucing-Kucingan (Achalpa indica L.) pada Tikus Putih Betina Galur Wistar (Rattus norvegicus L.) Jurnal Ilmiah Farmasi. 2(3): 4-8. 